\title{
THE GENETICS OF LEUKAEMIA IN MAN
}

\author{
By S. N. ARDASHNIKOV
}

From the Maxim Gorky Medico-Genetical Research Institute and the Bogdanov Central Institute of Clinical and Experimental Haematology and Blood Transfusion, Moscow

(With 4 Figures in the Text)

\section{INTRODUCTION}

DESPITE considerable research on the problem of leukaemia, its etiology is still obscure. Endocrine dysfunction, effect of X-ray, trauma and etiological features suggestive of malignant tumours have been advanced as possible causes. The very nature of the disease as well as data on leukaemia in fowls, favour the theory of an infectious origin. Poverty, physical and mental strain, lymphatic constitution, syphilis, malaria and other infectious diseases have been suggested, often on inadequate grounds, as predisposing factors in leukaemia. Interesting results were obtained by MacDowell and Richter on susceptibility of mice to leukaemia.

In view of the absence of adequate data on the role of heredity in leukaemia in man the present investigation was undertaken on the suggestion of Dr Levit.

\section{Material}

In all, thirty-three pedigrees were collected. Twenty-seven were based on information supplied by patients, and the others, due to the serious condition or death of the patient, were based on information supplied by nearest relatives. Moreover, one pedigree was excluded from subsequent calculations because it was directed to us as a hereditary case. ${ }^{1}$ The pedigrees cover from eight to one hundred and eighty-three persons and include from two to six generations. Most of the probands were treated at the Institute for Blood Transfusion. The patients may be divided into the following groups, according to nationality: Russians 26, Jews 7, Armenians 1, Bulgarians 1, Latvians 1. Age, sex and form of the disease are shown in Table I.

The greater frequency of affected males as well as the age distribution of the group with myeloid leukaemia are in agreement with data in the literature. On the other hand, most of the patients with lymphatic leukaemia were of more advanced age than those usually described which may be explained by the limited number of cases.

1 Cases that are directed to us because they are hereditary we name "selected" cases. 


\section{Familial cases}

There were only three pedigrees of familial cases.

In the first familial case (see Fig. 1) the proband (III, 4) suffered from typical chronic myeloid leukaemia: enlarged liver, large, congested and painful spleen, and slightly enlarged lymphatic glands. Blood analysis showed:

Haemoglobin
Erythrocytes
Leucocytes
Polynuclears
Rodnuclears
Basophils
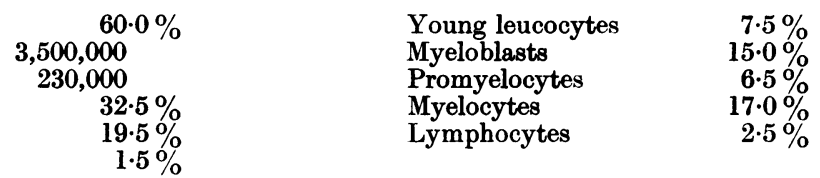

together with 2 normoblasts, 1 erythroblast, and a little anisocytosis. According to the patient, her mother's brother B. (II, 8) died from leukaemia at the age

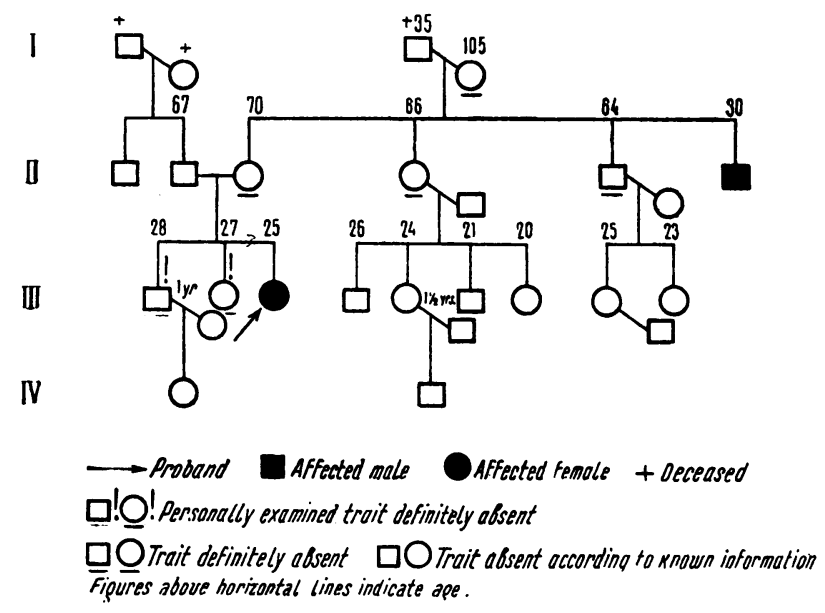

Fig. 1

of 30. The patient's mother in reply to our letter wrote that "my brother B. suffered from leukaemia for about a year. According to physicians he had a lot of white corpuscles in his blood." Examinations of the patient's brother (28 years) and sister (27 years) were negative.

The second familial case (see Fig. 2) ${ }^{1}$ concerns patient S. (III, 8) who was dead at the time of our investigation. The anamnesis shows that the first symptoms of the disease, the swelling of left super-cervical glands, were noted by the patient in 1929. A blood analysis revealed leukaemia. When the patient entered the clinic the lymphatic glands were enlarged, movable, painless, consistently soft: spleen congested, the liver protruding $4 \mathrm{~cm}$. from the costal margin. Blood analysis showed:

\begin{tabular}{lclr} 
Haemoglobin & $\mathbf{6 3} \%$ & Polynuclears & $5 \%$ \\
Erythrocytes & $\mathbf{3 , 9 2 0 , 0 0 0}$ & Large lymphocytes & $10 \%$ \\
Leucocytes & $\mathbf{5 4 , 2 0 0}$ & Small lymphocytes & $\mathbf{8 5} \%$ \\
\hline
\end{tabular}

1 The significance of signs employed in Figs. 2, 3 and 4 is explained in Fig. 1. 
D
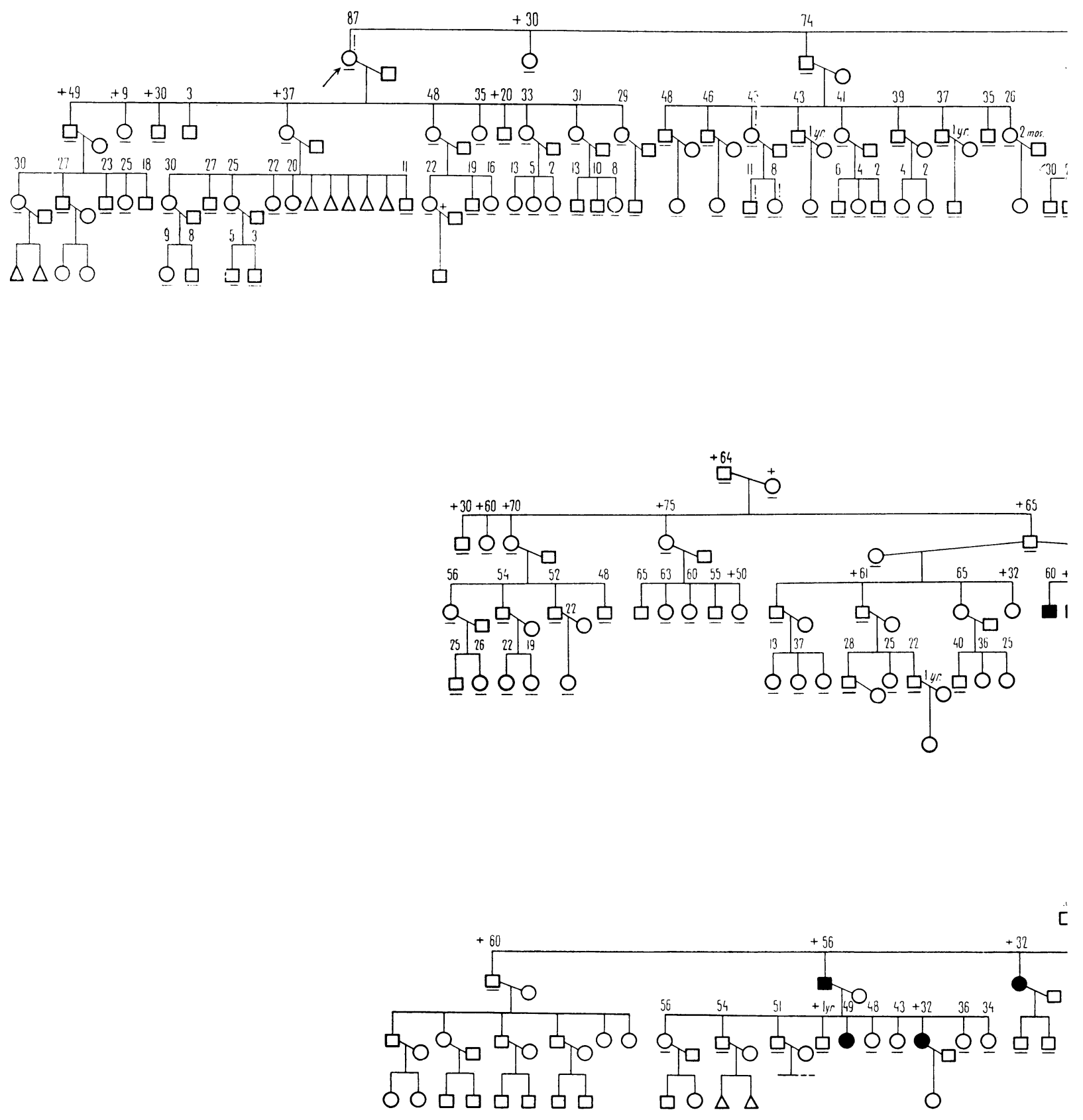


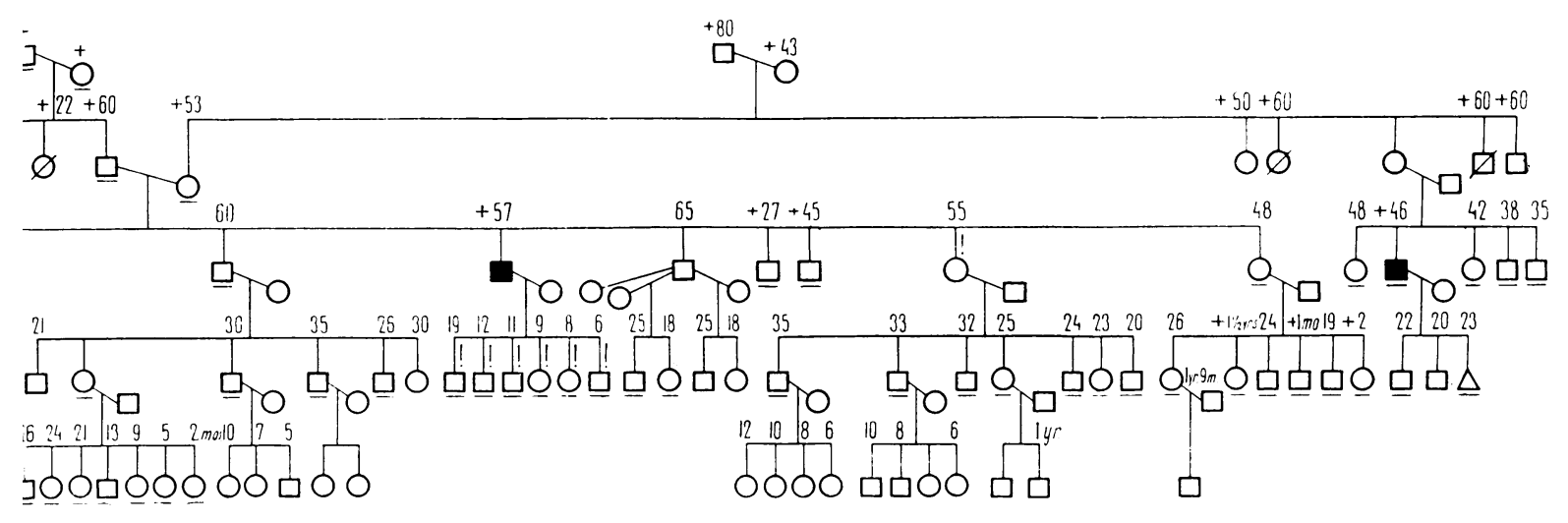

DDinformationlacking $\triangle$ iex whonow?

Fig. 2

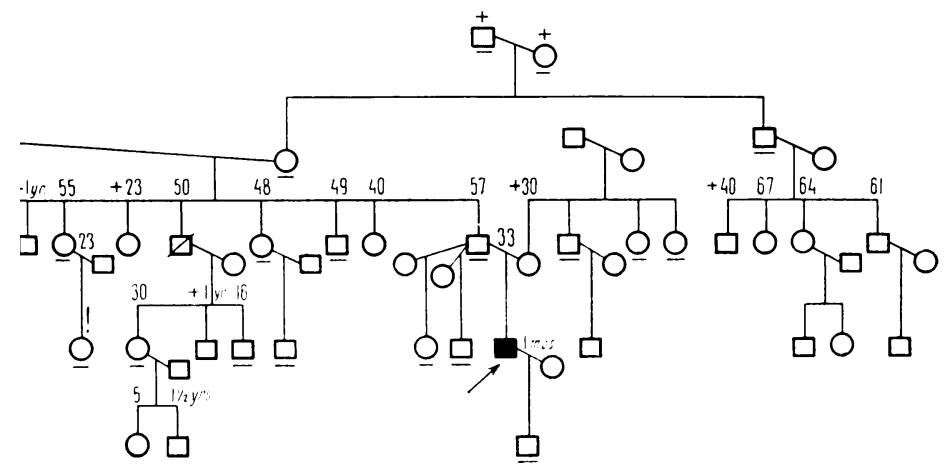

Fig. 3

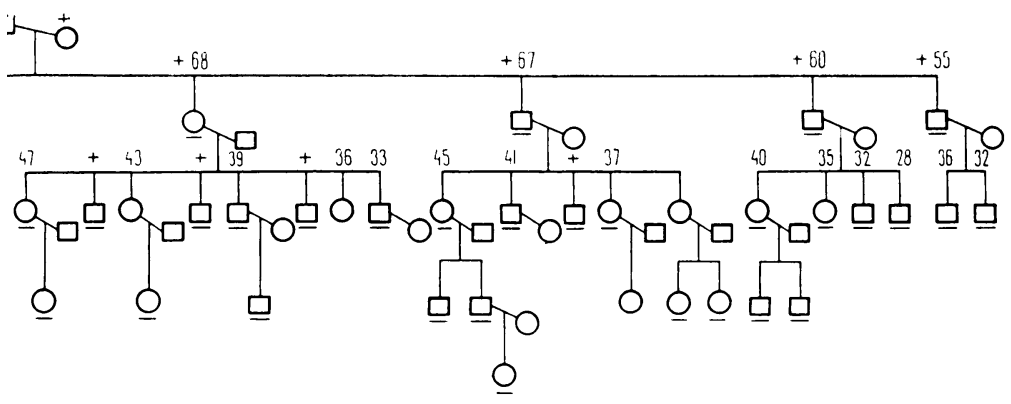

Fig. 4 


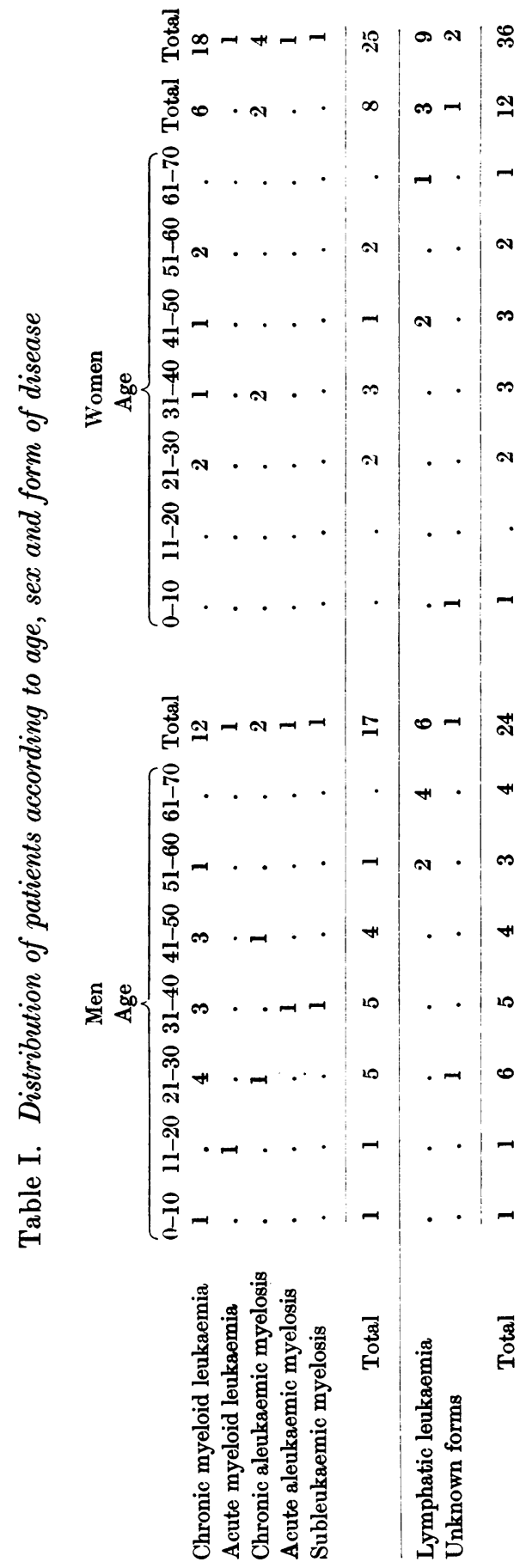


Early in 1932 the patient died. Since he was not observed directly, we quote the following regarding the autopsy: "Corpse of a male of advanced age, poorly fed, legs swollen, the cervical, axillary and especially the inguinal glands enlarged. The skin above the glands movable. Hyperplasia of the spleen." No doubt a case of typical chronic lymphatic leukaemia.

The patient's pedigree was based on the evidence of his wife (III, 9) and sister (III, 16), later confirmed by his eldest sister (III, 1), brother (III, 4) and niece (IV, 22). According to them, the patient's cousin on his mother's side (III, 21) died from leukaemia at 45. The disease lasted for several years. He had "scirrhus" on the neck and under the armpits just as our patient had.

The sister, niece, grand-nephew, grand-niece and offspring of the proband were examined. The grand-niece ( $v, 36)$ had lymphocytosis (57 per cent) which was possibly caused by a chronic tubercular intoxication. An examination of other members of the family gave negative findings.

The third familial case G. (see Fig. 3) is of special interest, since the members of this family suffered from different forms of leukaemia.

B. (Iv, 25), 33 years old, became ill in 1930. The illness began with a sudden chill and rise in temperature. A diagnosis of malaria was made, but not confirmed by blood examination, which later revealed changes peculiar to myeloid leukaemia. X-ray treatment produced considerable improvement. Towards the middle of 1933 there was marked change for the worse. The patient came to the clinic with complaints of general weakness, palpitation, difficult breathing, headaches and rising temperature. Examination revealed an enlarged liver, a large, congested spleen and enlarged lymphatic glands. One of the last blood analyses (3 January 1934) showed:
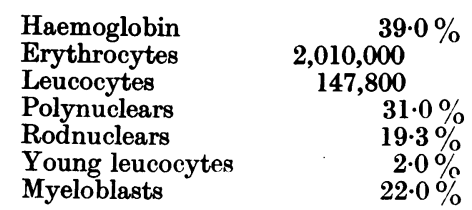

Promyelocytes
Myelocytes
Lymphocytes
Basophils
Normoblasts
Eosinophils
Hystiocytes

$$
\begin{array}{r}
2.0 \% \\
5 \cdot 0 \% \\
0 \cdot 6 \% \\
15 \cdot 3 \% \\
5 \cdot 3 \% \\
2.0 \% \\
0.6 \%
\end{array}
$$

together with anisocytes, poikilocytes, erythroblasts and erythrocytes with basophile punctuation. Autopsy confirmed the clinical diagnosis of myeloid leukaemia. "Hyperplasia of lymphatic glands : submaxillary, cervical, axillary, inguinal and paraperitoneal. Hyperplasia of the spleen. Myeloid hyperplasia of the marrow. Anaemia of all organs. Subcutaneous lymphatic glands enlarged. Mesenteric glands somewhat enlarged. Bronchial glands enlarged, 5-6 cm. in diameter. Lymphatic glands at the root of the tongue and tonsils very much enlarged. Spleen congested. On cross-section cherry-red colour, hard to cut. Malpighian corpuscles not visible. Enlarged glands in the porta hepatica. The liver pale and stagnated in cross-section."

An analysis in 1925 of the blood of the patient's uncle B. (III, 20), 60 years old, revealed 70,000 leucocytes, and 90 per cent lymphocytes. In 1930 the number of leucocytes decreased to 20,000 . The number of lymphocytes varied between 90 and 96 per cent. A diagnosis of lymphatic leukaemia was made. 
The blood picture remained more or less the same, as was shown by numerous analyses in different laboratories, made before our investigation in 1934 . Examination showed enlarged inguinal, axillary and cervical glands, as well as an enlarged spleen protruding four finger-breadths from the costal margin. A case of lymphatic leukaemia.

An examination of the aunt (III, 22) of the proband (also the sister of the second) gave a negative result. Her daughter N. (Iv, 17) 23 years old, complained of considerable fatigue and headaches. Blood analysis:

$\begin{array}{lclr}\text { Haemoglobin } & 52 \% & \text { Lymphocytes } & \mathbf{5 7} \% \\ \text { Erythrocytes } & \mathbf{4 , 1 5 0 , 0 0 0} & \text { Eosinophils } & \mathbf{2} \% \\ \text { Leucocytes } & \mathbf{4 , 0 0 0} & \text { Monocytes } & \mathbf{4} \% \\ \text { Polynuclears } & \mathbf{3 6} \% & & \end{array}$

The pedigree of the "selected" case (see Fig. 4) was based on the report of a physician, a member of the family (III, 27), who was well informed on the state of the fraternity. Three members of the family died of leukaemia. Further information was obtained from another member of the family, a patient, also a physician (III, 18), who underwent treatment. She also confirmed the information obtained from the proband.

In October 1932, the patient (III, 18) fell ill with chronic leukaemia: hyperplasia of the cervical, submaxillary, axillary and inguinal glands. In the left axillary region there was a small glandular pocket. The spleen palpable three finger-breadths below the costal margin. Blood analysis showed:

Haemoglobin
Erythrocytes
Leucocytes
Polynuclears
Lymphocytes$$
\begin{array}{r}
80 \cdot 0 \% \\
3,960,000 \\
162,000 \\
4 \cdot 4 \% \\
93 \cdot 6 \%
\end{array}
$$$$
\begin{array}{lr}
\text { Basophils } & 0.8 \% \\
\text { Eosinophils } & 0 \cdot 8 \% \\
\text { Monocytes } & 0 \cdot 1 \% \\
\text { Thrombocytes } & 102,000
\end{array}
$$

It is interesting to note that a blood analysis in 1928 showed a considerable lymphocytosis (55.5 per cent) to which the patient did not pay any attention at that time.

Patient's father (II, 3). Myeloid leukaemia was first diagnosed in 1908. Underwent X-ray treatment. Died of leukaemia at the age of 60 . His sister (II, 5) became ill in 1898, at the age of 27 . She had enlarged glands, especially in the cervical region. Underwent treatment in St Petersburg and abroad. Died in 1898. Patient's sister (II, 21) suffered from leukaemia. She also had anaemia of a pernicious type. Her sister (III, 24) was examined at the age of 34. Findings negative.

Thus, in only three cases out of thirty-three pedigrees, excluding the "selected" case, was the disease of a familial nature.

\section{Familial cases in the literature}

It is known that familial cases of leukaemia are rare. Thus Naegeli speaking of chronic myeloid leukaemia wrote in 1927 that "the existence of familial cases of this disease has not been stated". It is true that in the fifth edition of the book (1931) he writes "there are occasional familial cases of leukaemia", 
and he confirms this statement with a report of a family where the sister suffered from chronic myeloid and the brother from lymphatic leukaemia, and by the cases of Barrenscheen and Hirschfeld.

Table III gives a summary of familial cases of leukaemia found in the literature, as well as our own cases.

It cannot be denied that some of the cases cited in the summary are doubtful ones. In cases reported by Biermer, Senator, Jewett and Ortner, children 75 days to $4 \frac{1}{2}$ years old suffered from leukaemia. The primary symptoms were anaemia and an enlarged spleen. Since leukaemia is very rare at so early an age and since there was an absence of other symptoms of leukaemia, it would have been more correct to consider these simply as unknown infections. Similarly such cases as those reported by Schmorl, Mannaberg, and the socalled "American case", which are based upon superficially investigated data and are very briefly described, cannot be considered as entirely authentic. Other cases that have been reported raise no doubts.

\section{Are familial cases of leukaemia due to chance?}

Though it is true that the cases described in the literature are "selected" cases and are reported because of the familial nature of the disease, the occurrence of a very rare disease in several members of the same family cannot be said to be due to chance alone. Particularly is this true for our cases which have been collected systematically, i.e. the collection of all available material and not recourse to hereditary cases only.

Since the incidence and mortality of leukaemia is not accurately known, we cannot introduce our figures here for comparison, but it can be said with safety that the proportion of affected among the relatives $(3: 521)$ could hardly be attributed to chance occurrence.

Arguing against a hypothesis of chance occurrence is the fact that among familial cases lymphatic leukaemia is more often met than myeloid leukaemia, although the reverse should be true if it were due to chance, since myeloid forms of leukaemia occur three times more often than lymphatic leukaemia.

Table II includes familial cases appearing in the summary, distributed according to the nature of the disease.

\section{Table II}

$\begin{array}{lc}\text { Type of disease among familial cases } & \text { No. of } \\ \text { cases } \\ \text { Lymphatic leukaemia } & 13 \\ \text { Myeloid leukaemia } & 2 \\ \text { Lymphatic and myeloid leukaemia } & 6 \\ \text { Unknown forms of leukaemia } & 5 \\ \text { Lymphatic and unknown forms of leukaemia } & 2 \\ \text { Myeloid and unknown forms of leukaemia } & 3\end{array}$

As is evident from this table, the ratio of familial cases with lymphatic forms to familial cases with myeloid forms is $6: 1$. Moreover, it should be added that the majority of familial cases of myeloid leukaemia as well as 
Table III.

\begin{tabular}{|c|c|c|c|c|c|c|c|c|}
\hline Disease & Author and year & $\begin{array}{l}\text { Age at } \\
\text { onset of } \\
\text { disease }\end{array}$ & Sex & Form of disease & Duration & $\begin{array}{l}\text { Interval } \\
\text { between } \\
\text { affection } \\
\text { of 1st and } \\
\text { 2nd members } \\
\text { of family }\end{array}$ & $\begin{array}{l}\text { Kinship (of } \\
\text { 2nd member } \\
\text { of family) }\end{array}$ & $\begin{array}{l}\text { Age at onset } \\
\text { of disease }\end{array}$ \\
\hline \multirow{7}{*}{$\begin{array}{r}\text { Lymphatic } \\
\text { leukaemia }\end{array}$} & Brandenberg, 1909 & $\begin{array}{l}\text { Several } \\
\text { months }\end{array}$ & $\hat{3}$ & $\begin{array}{l}\text { Chronic } \\
\text { aleukaemic }\end{array}$ & - & - & Brother & $\begin{array}{l}\text { Several } \\
\text { months }\end{array}$ \\
\hline & Weisz, 1911 & $15 \mathrm{yr}$. & 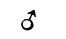 & Chronic & $5 \mathrm{yr}$. & $10 \mathrm{yr}$. & Sister & - \\
\hline & $\begin{array}{l}\text { Decapite, } 1924 \\
\text { Hirschfeld, H., } 1925\end{array}$ & $\begin{array}{l}6 \mathrm{mos} . \\
67 \mathrm{yr} .\end{array}$ & $\begin{array}{l}\hat{\sigma} \\
\hat{\sigma}\end{array}$ & $\begin{array}{l}\text { Chronic } \\
\text { Chronic } \\
\text { aleukaemic }\end{array}$ & $\begin{array}{l}\text { Over } 2 \text { yr. } \\
\text { Over } 7 \text { yr. }\end{array}$ & $2 \frac{1}{2} \mathrm{yr}$. & $\begin{array}{l}\text { Brother } \\
\text { Brother }\end{array}$ & $\begin{array}{l}1 \mathrm{mo} . \\
70 \mathrm{yr} .\end{array}$ \\
\hline & Rosenow, 1925 & $42 \mathrm{yr}$ & ot & Chronic & - & - & Mother & $71 \mathrm{yr}$. \\
\hline & $\begin{array}{l}\text { Schereschewsky, } \\
1926\end{array}$ & 54 yr. & q & Chronic & Over 2 yr. & Soon after & Brother & $61 \mathrm{yr}$. \\
\hline & $\begin{array}{l}\text { Vercelotti, 1926 } \\
\text { Brügger, 1927 } \\
\text { Riccitelli \& Ragnotti, } \\
1927\end{array}$ & $\begin{array}{l}55 \text { yr. } \\
78 \text { days } \\
65 \text { yr. }\end{array}$ & $\begin{array}{l}9 \\
+ \\
+ \\
+ \\
0\end{array}$ & $\begin{array}{l}\text { Chronic } \\
\text { Acute } \\
\text { Chronic }\end{array}$ & $\begin{array}{l}3 \text { yr. } \\
4 \text { days } \\
5 \text { yr. }\end{array}$ & $\begin{array}{l}2 \frac{1}{2} \mathrm{yr} . \\
1 \frac{1}{2} \mathrm{yr} .\end{array}$ & $\begin{array}{l}\text { Brother } \\
\text { Sister } \\
\text { Daughter }\end{array}$ & $\begin{array}{l}59 \text { yr. } \\
105 \text { days } \\
43 \text { yr. }\end{array}$ \\
\hline & $\begin{array}{l}\text { Dameshek et al. } 1929 \\
\text { Petri, 1933 } \\
\text { Morawitz, 1933 } \\
\text { Ardashnikov, } 1934\end{array}$ & $\begin{array}{l}56 \mathrm{yr} . \\
53 \mathrm{yr} . \\
59 \mathrm{yr} . \\
\text { Died, } \\
45 \mathrm{yr} \text {. old }\end{array}$ & $\begin{array}{l}\hat{0} \\
\hat{0} \\
\hat{0} \\
\hat{0}\end{array}$ & $\begin{array}{l}\text { Chronic } \\
\text { Chronic } \\
\text { Chronic } \\
\text { Chronic }\end{array}$ & $\begin{array}{l}2 \frac{1}{2} \text { yr. } \\
4 \text { yr. } \\
\text { Over } 1 \text { yr. } \\
\text { Several } \\
\text { years }\end{array}$ & $\begin{array}{l}11 \text { yr. } \\
\text { ca. same time } \\
3 \text { mos. } \\
3 \text { yr. }\end{array}$ & $\begin{array}{l}\text { Twin brother } \\
\text { Brother } \\
\text { Brother } \\
\text { Cousin }\end{array}$ & $\begin{array}{l}57 \frac{1}{2} \text { yr. } \\
51 \text { yr. } \\
57 \text { yr. } \\
54 \text { yr. }\end{array}$ \\
\hline \multirow{2}{*}{$\begin{array}{l}\text { Myeloid } \\
\text { leukaemia }\end{array}$} & Casati, 1872 & $10 \mathrm{yr}$. & q & - & - & 一 & Father & - \\
\hline & $\begin{array}{l}\text { Senator, } 1882 \\
\text { Jewett, 1901 } \\
\text { Arnsperger, } 1905 \\
\text { Schmorl, } 1911\end{array}$ & $\begin{array}{l}11 \mathrm{yr} . \\
7 \mathrm{mos} . \\
\text { Three relati }\end{array}$ & $\begin{array}{r}0 \\
+ \\
q \\
+ \\
+ \\
\text { ves }\end{array}$ & $\begin{array}{l}\text { Subacute } \\
\text { Acute }\end{array}$ & 2 mos. & $\begin{array}{l}\text { At same time } \\
6 \mathrm{yr} .\end{array}$ & $\begin{array}{l}\text { Twin sister } \\
\text { Brother } \\
\text { Sister }\end{array}$ & $\begin{array}{l}1 \frac{1}{2} \text { yr. } \\
5 \text { mos. } \\
35 \text { yr. }\end{array}$ \\
\hline \multirow{5}{*}{$\begin{array}{l}\text { Myeloid and } \\
\text { lymphatic } \\
\text { leukaemia }\end{array}$} & $\begin{array}{l}\text { Eppinger, } 1911 ; \\
\text { Barrenscheen, } 1912\end{array}$ & $38 \mathrm{yr}$. & q & Acute myeloid & 7 days & Soon after & Brother & - \\
\hline & MacGavran, 1922 & $40 \mathrm{yr}$. & $\hat{0}$ & Chronic myeloid & - & $5 \mathrm{yr}$. & Brother & $59 \mathrm{yr}$. \\
\hline & $\begin{array}{l}\text { Naegeli, } 1931 \\
\text { Steiner, } 1933\end{array}$ & $59 \overline{\mathrm{yr}}$ & $\begin{array}{l}\text { q } \\
\text { ô }\end{array}$ & $\begin{array}{l}\text { Chronic myeloid } \\
\text { Aleukaemic } \\
\text { lymphatic }\end{array}$ & $6 \overline{\mathrm{mos}}$. & $6 \mathrm{yr}$. & $\begin{array}{l}\text { Brother } \\
\text { Brother }\end{array}$ & $58 \overline{\mathrm{yr}}$. \\
\hline & Ardashnikov, 1934 & $27 \mathrm{yr}$. & 우 $-100-10$ & Lymphatic & 2 yr. & $10 \mathrm{yr}$. & Brother & $56 \mathrm{yr}$. \\
\hline & Ardashnikov, 1934 & 53 yr. & 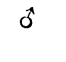 & $\begin{array}{l}\text { Chronic } \\
\text { lymphatic }\end{array}$ & $\begin{array}{l}\text { Longer } \\
\text { than } 9 \mathrm{yr} .\end{array}$ & $5 \mathrm{yr}$. & $\begin{array}{l}\text { Nephew, on } \\
\text { father's side }\end{array}$ & $30 \mathrm{yr}$. \\
\hline \multirow[t]{2}{*}{$\begin{array}{l}\text { Unknown } \\
\text { forms }\end{array}$} & $\begin{array}{l}\text { Eichhorst, } 1897 \\
\text { Eichhorst, } 1897 \\
\text { Greene, } 1888 \\
\text { Cameron, } 1888\end{array}$ & $\begin{array}{l}12 \mathrm{yr} . \\
4 \mathrm{yr} . \\
15 \mathrm{yr} . \\
36 \mathrm{yr} .\end{array}$ & $\begin{array}{l}0 \\
0 \\
0 \\
0 \\
+ \\
+\end{array}$ & $=$ & $\begin{array}{l}\overline{-} \\
9 \text { mos. } \\
\text { Over } 4 \text { yr. }\end{array}$ & $\begin{array}{l}\text { - } \\
5 \text { yr. } \\
6 \text { mos. }\end{array}$ & $\begin{array}{l}\text { Male cousin } \\
\text { Brother } \\
\text { Sister } \\
\text { Son }\end{array}$ & $\begin{array}{l}12 \overline{\mathrm{yr}} \\
21 \mathrm{yr} . \\
6 \mathrm{mos} .\end{array}$ \\
\hline & $\begin{array}{l}\text { Ortner, } 1891 \\
\text { Rosenhaupt, } 1915 \\
\text { Mannaberg }\end{array}$ & $\frac{\overline{-}}{\text { Case Bauer }}$ & $\begin{array}{c}\text { } \\
\text { o } \\
\text { cit., nc }\end{array}$ & $\begin{array}{l}\text { Acute } \\
\text { details }\end{array}$ & - & 9 yr. & $\begin{array}{l}\text { Sister } \\
\text { Grandchild }\end{array}$ & $\begin{array}{l}8 \frac{1}{2} \text { mos. } \\
2 \text { yr. }\end{array}$ \\
\hline \multirow{2}{*}{$\begin{array}{l}\text { Lymphatic } \\
\text { and unknown } \\
\text { forms }\end{array}$} & Hanszel, 1908 & - & ot & Acute & $\begin{array}{c}\text { Several } \\
\text { weeks }\end{array}$ & $\begin{array}{c}\text { Several } \\
\text { years }\end{array}$ & $\begin{array}{l}\text { Maternal } \\
\text { uncle }\end{array}$ & $20 \mathrm{yr}$. \\
\hline & Hirschfeld, H., 1925 & $70 \mathrm{yr}$. & q & - & 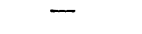 & 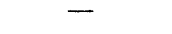 & Brother & $60 \mathrm{yr}$. \\
\hline \multirow{2}{*}{$\begin{array}{l}\text { Myeloid and } \\
\text { unknown } \\
\text { forms }\end{array}$} & $\begin{array}{l}\text { Biermer, } 1861 \\
\text { Campbell, } 1912\end{array}$ & $2 \mathrm{yr}$. & 우 & Chronic & $2 \frac{1}{2} \mathrm{yr}$ & $\begin{array}{l}1 \frac{1}{2} \text { yr. } \\
\text { Practically }\end{array}$ & $\begin{array}{l}\text { Sister } \\
\text { Mother }\end{array}$ & 3 yr. \\
\hline & Ardashnikov, 1934 & $30 \mathrm{yr}$. & o & Chronic & - & 30 yr. & $\begin{array}{l}\text { Niece, on } \\
\text { mother's side }\end{array}$ & $25 \mathrm{yr}$. \\
\hline
\end{tabular}




\section{$A$ summary}

\begin{tabular}{|c|c|c|c|c|c|c|c|}
\hline Form of disease & Duration & $\begin{array}{l}\text { Interval } \\
\text { between } \\
\text { affection } \\
\text { of } 2 \text { nd and } \\
\text { 3rd members } \\
\text { of family }\end{array}$ & $\begin{array}{l}\text { Kinship (of } \\
\text { 3rd member } \\
\text { of family) }\end{array}$ & $\begin{array}{l}\text { Age at onset } \\
\text { of disease }\end{array}$ & $\begin{array}{l}\text { Form of } \\
\text { disease }\end{array}$ & Duration & $\begin{array}{l}\text { Other affected } \\
\text { relatives }\end{array}$ \\
\hline $\begin{array}{l}\text { Chronic } \\
\text { aleukaemic }\end{array}$ & - & - & Brother & $\begin{array}{l}\text { Several } \\
\text { months }\end{array}$ & $\begin{array}{l}\text { Chronic } \\
\text { aleukaemic }\end{array}$ & - & Brother \\
\hline Chronic & $4 \frac{1}{2} \mathrm{yr}$ & $6 \mathrm{yr}$. & Brother & - & $\begin{array}{l}\text { Acute or sub- } \\
\text { acute }\end{array}$ & $1 \frac{1}{2} \mathrm{yr}$. & - \\
\hline Chronic & $\begin{array}{l}\text { Over } 4 \text { mos. } \\
-\end{array}$ & - & - & - & - & - & 二 \\
\hline $\begin{array}{l}\text { Subleukaemic, later } \\
\text { changing to leu- } \\
\text { kaemic }\end{array}$ & - & - & - & - & - & - & - \\
\hline Chronic & Over 2 yr. & - & - & - & - & - & - \\
\hline $\begin{array}{l}\text { Subacute } \\
\text { Acute } \\
\text { Chronic }\end{array}$ & $\begin{array}{l}7 \text { mos. } \\
13 \text { days } \\
\text { Over } 3 \frac{1}{2} \text { yr. }\end{array}$ & $1 \mathrm{yr}$ - & $\begin{array}{l}\text { Sister } \\
\text { Daughter }\end{array}$ & $\begin{array}{l}\text { 78 days } \\
\text { Over } 44 \text { yr. }\end{array}$ & $\begin{array}{l}\text { Acute } \\
\text { Chronic }\end{array}$ & 6 dayss & Female cousin \\
\hline $\begin{array}{l}\text { Chronic } \\
\text { Chronic } \\
\text { Chronic } \\
\text { Chronic }\end{array}$ & $\begin{array}{l}11 \text { yr. } \\
4 \text { yr. } \\
\text { Over } 1 \text { yr. } \\
3 \text { yr. }\end{array}$ & - & $\begin{array}{l}- \\
z\end{array}$ & $\frac{-}{E}$ & $\begin{array}{l}\overline{-} \\
\overline{-}\end{array}$ & $\bar{z}$ & $\begin{array}{l}- \\
\overline{-}\end{array}$ \\
\hline - & - & - & $\begin{array}{l}\text { Paternal grand- } \\
\text { father or great- } \\
\text { grandfather }\end{array}$ & - & - & - & - \\
\hline $\begin{array}{l}\text { Subacute } \\
\text { Acute }\end{array}$ & $\begin{array}{l}3 \text { mos. } \\
6 \text { mos. } \\
\text { Over } 2 \text { yr. }\end{array}$ & - & Sister & 4 mos. & E & E & 二 \\
\hline Lymphatic & - & $\begin{array}{l}c a .1 \mathrm{yr} . \\
\text { earlier }\end{array}$ & $\begin{array}{c}\text { Female } \\
\text { cousin }\end{array}$ & $\cdots$ & - & - & - \\
\hline Acute lymphatic & $1 \frac{1}{2}$ mos. & At same time & Paternal uncle & $69 \mathrm{yr}$. & $\begin{array}{l}\text { Subacute } \\
\text { lymphatic }\end{array}$ & Over 10 mos. & - \\
\hline $\begin{array}{l}\text { Lymphatic } \\
\text { Chronic submyeloid }\end{array}$ & Over $\overline{6}$ mos. & $\overline{-}$ & E & 二 & 二 & 二 & - \\
\hline Chronic myeloid & $4 \mathrm{yr}$. & $25 \mathrm{yr}$. & $\begin{array}{l}\text { Daughter (of } \\
\text { second) }\end{array}$ & $49 \mathrm{yr}$. & $\begin{array}{l}\text { Chronic } \\
\text { lymphatic }\end{array}$ & Over 2 yr. & $\begin{array}{l}\text { Daughter (of } \\
\text { second) }\end{array}$ \\
\hline Chronic myeloid & $4 \mathrm{yr}$. & - & - & - & - & - & - \\
\hline${ }_{\text {Acute }}=$ & $\begin{array}{l}- \\
6 \text { mos. } \\
3 \text { mos. }\end{array}$ & Soon after & $\begin{array}{l}\quad \text { - } \\
\text { Sister } \\
\text { Son } \\
\text { Daughter }\end{array}$ & $\begin{array}{l}18 \mathrm{yr} . \\
15 \mathrm{yr} . \\
11 \mathrm{yr} .\end{array}$ & $\bar{z}$ & Cured (?) & $\begin{array}{l}\text { - } \\
\text { Brother, } \\
\text { mother, great- } \\
\text { grandmother }\end{array}$ \\
\hline -- & - & E & - & $\overline{-}$ & $\overline{-}$ & - & 二 \\
\hline Acute & $1 \mathrm{mo}$ & - & - & - & - & - & - \\
\hline Lymphatic & - & - & - & - & - & - & - \\
\hline $\begin{array}{l}\text { Chronic } \\
\text { Myeloid }\end{array}$ & Over $1 \mathrm{yr}$. & - & 二 & $\overline{-}$ & - & - & - \\
\hline Chronic myeloid & Over 4 yr. & - & - & - & - & 一 & - \\
\hline
\end{tabular}


familial cases of unknown forms lend question to authenticity of diagnosis. Thus the fact that there is a prevalence of lymphatic leukaemia in familial cases becomes significant and indicates that the results are not due to coincidence.

We can arrive at the same conclusion in still another way. Dr Presnyakov of the Medico-Genetical Institute has been studying the genetics of pernicious anaemia and to date has examined 100 families. In spite of the fact that he was seeking cases of leukaemia in these families, among the 528 relatives of over 20 years of age (for whom information was available) he found no case of leukaemia and three cases of pernicious anaemia.

Although we looked for other blood diseases also, among the relatives in our cases, some of whom were personally examined, we could find no case of pernicious anaemia, although the latter is met with as frequently if not more frequently in the population than is leukaemia. Thus the difference between the incidence of leukaemia among relatives of our patients and among relatives of patients having pernicious anaemia was $3 \cdot 0$ or $1.75 \sigma$. Although this difference cannot be regarded as fully significant statistically (the probability of the existence by chance of this or a greater difference is only 0.0891), considered together with the other data, it substantiates our hypothesis that familial forms of leukaemia are not due to chance.

\section{ON THE INHERITANCE OF LEUKAEMIA}

Rejecting a hypothesis of chance occurrence we must either assume some specific external intrafamilial factors (such as infection) or assume the influence of hereditary factors.

There are comparatively few available data on contagiousness of leukaemia in man (Obrastzov, Aubertin \& Grellety-Bosvil, and Arnsperger). The numerous bacteria that have been found in the blood of people suffering from leukaemia is merely evidence of the susceptibility of the patients to secondary infections. The inoculation of humans with leukaemia has given negative results. Inflammations and pathological forms of neutrophils, as well as an increase of globulin, are absent in leukaemia. Moreover, offspring of affected mothers suffering from leukaemia are born healthy, and an affected foetus does not injure the mother.

From an analysis of our familial cases a few new facts appear which further argue against a contagious origin of leukaemia. In one of our first cases where an uncle and niece were affected, the latter was born 2 years after the uncle's death, and became ill 28 years later. It may be argued that the mother of the proband became latently affected through her affected brother and then passed on the disease to her daughter, with whom she was in contact. But it is difficult to explain why the elder brother and sister were not affected, since they too lived under conditions similar to our proband. Even if we admit in this case the plausibility of an infectious origin we may still assume an inherited 
predisposition. In the second case, the proband and his cousin lived in different localities and there was no means of direct contact.

In the "selected" case (family B.) considerable time elapsed between illnesses. The proband's aunt on the father's side became ill in 1898, and died in 1900. The father became ill in 1908 and died in 1912, and the proband herself became ill in 1932. The majority of the cases in the literature show that a considerable amount of time elapsed between the illnesses of different members of the same family.

The strongest objection to a hypothesis favouring common environmental influences (including infection) as causes of leukaemia is the fact that there has been no recorded case of the disease in both husband and wife.

Thus, the presence of familial cases described in this communication together with the familial cases described in the literature-cases which cannot be explained as due to common environmental influences-favour the hypothesis that hereditary factors exert an influence in the etiology of leukaemia.

\section{The question OF THE BIOLOGICAL COMMUNALITY OF DIFFERENT FORMS OF LEUKAEMIA}

The majority of haematologists divide leukaemia into lymphatic and myeloid groups. Some investigators disapprove of such a sharp division, since there are cases of leukaemia where rejuvenation of the blood presents difficulties in haematological classification. Moreover, other cases of mixed leukaemia have been described where lymphocytes and myelocytes were present in the blood together. These facts and the cases of Eppinger, MacGavran, Naegeli, Steiner, and our families G. and B. where various forms of leukaemia occur in one family, clearly indicate some interrelation between these forms of leukaemia. Any hypothesis of chance occurrence to explain the presence of various forms of leukaemia within one family may be rejected for the same reasons as have been suggested for familial cases in general. Thus the presence of the various forms of leukaemia in several members of one family confirms clinical findings, namely, that in some cases a certain communality of both forms is probably conditioned by common etiological factors.

\section{THE MODE OF INHERITANCE OF LEUKAEMIA}

However, if leukaemia is at least partly due to genotypical factors then its mode of inheritance presents an extremely difficult problem. In our pedigrees we found affected offspring of healthy parents which suggests the possibility of a recessive type of inheritance. But taking into consideration the rarity of the disease, we should expect a large percentage of inbreeding. Moreover, if due to a recessive gene (which in man has generally a high penetrance), approximately $1: 4$ of the 122 brothers and sisters among the patients should have suffered from leukaemia, which is not so in our material. 
There is a likelihood that leukaemia may be due to a conditionally dominant ${ }^{1}$ gene whose manifestation is influenced to a large extent by other gene modifiers or by external factors. The mode of inheritance in our familial cases favours a hypothesis of dominant inheritance. In family B. there was a direct transmittance of the disease from father to offspring. In the first case where the uncle and niece were affected, its absence in the proband's mother might be explained as a skip. The same was true for the Cazati and Rosenow cases.

\section{ON THE PENETRANCE OF LEUKAEMIA}

In view of the rarity of familial cases, can the influence of hereditary factors be said to exist for leukaemia in general? Actually, only 9 per cent of our material include familial cases. ${ }^{2}$ This may be due to an arbitrary classification of hereditary and non-hereditary forms of leukaemia into one group. As a matter of fact this seems to be the case, so far as we can judge from the literature and from our findings. As was previously mentioned, myeloid forms of leukaemia are six or seven times more frequent than lymphatic forms. It follows that familial cases with myeloid forms, if due to chance, should also be six to seven times more frequent than those with lymphatic forms. At the same time the number of familial cases of chronic lymphadenosis, as well as familial cases with both forms of leukaemia, by far exceed the number of familial cases with chronic myelosis. This fact, and what has been said about the external intrafamilial factors, point to the presence of hereditary factors in the origin of chronic lymphadenosis. This is probably also true for the myeloses which were observed in the family with lymphadenosis, and which, as we have shown above, have an etiological communality with lymphadenosis.

The small number of familial cases with other forms of myelosis points to a possible paratypical origin of this disease. This is indirectly confirmed by the fact that with the introduction of more accurate methods of differentiation, almost all cases of acute leukaemia have been diagnosed as myeloid leukaemia. This classification into one group of hereditary and paratypical forms of leukaemia may create an apparent rareness of familial cases. The material is too small to show that hereditary factors cause lymphatic leukaemia in all cases. Moreover, if the theory of evolution of dominance in man as suggested by Levit is tenable, then it is possible to suppose that the rarity may depend upon the poor penetrance of the gene whose evolution has already proceeded so far that it has become partly recessive.

1 A term suggested by Levit to include a type of dominant inheritance where it is uncertain that the homozygote $\mathbf{A A}$ is similar to the heterozygote $\mathbf{A a}$ and where the homozygous states of the disease are not known.

2 This figure may be an overestimation, since the investigation was discontinued after the third familial case (family G.). Among our pedigrees, familial cases were in the following order: first familial case-pedigree No. 14, second case-pedigree No. 26 and third case-pedigree No. 32. Although there is some regularity in the occurrence of these familial cases, it may be possible that three familial cases out of the total number of 33 are accidental and explained by the small number of cases. 


\section{ON THE EXPRESSION OF LEUKAEMIA}

In order to find "formes frustes" and atypical cases of leukaemia, thirtythree relatives of the patients were investigated (see Table IV). An anamnesis, clinical check-up, and a haematological analysis were obtained.

In one case a 30-year-old son of patient S. (pedigree II) had lymphocytosis (58.6 per cent) with a leucocyte count of 5400 , but without pathological signs to account for the condition.

In 1898 in family D. (pedigree 15) a 7-year-old girl died from leukaemia (her parents were cousins). In 1932 her brother became ill with tonsilitis; considerable weakness and general malaise remained after recovery. A blood analysis showed a leucocyte count of 18,100 and a large percentage (92) of lymphocytes. Diagnosed as "lymphatic leukaemia" the patient was directed to the clinic where a blood analysis still showed a relative lymphocytosis (80 per cent). The patient left the clinic with a diagnosis of "lymphatic reaction due to tonsilitis". Towards the end of 1932 a blood analysis was made disclosing an "absolute lymphocytosis (?)". Our examination of the patient in 1933 revealed no abnormality.

\section{Conclusions}

1. In some cases at least hereditary factors play a role in the etiology of leukaemia in man.

2. The most probable explanation is a conditionally dominant autosomal type of inheritance, especially in the lymphatic form of leukaemia, with great variation in the phenotype due to other genes or to external influences.

3. The existence of different forms of leukaemia in the same family indicates the presence of some communality of etiological factors in chronic myeloid and lymphatic leukaemia.

The author wishes to acknowledge his deep appreciation to Prof. S. G. Levit whose constant help made the investigation possible.

\section{REFERENCES}

Ardashnikov, S. (1934). On the genetics of Leukaemia. Proc. Maxim Gorky Med. Biol. Res. Inst., 3. Moscow. (Russian).

ARNSPERGER, L. (1905). Endemisches Auftreten von myeloider Leukämie. Münch. med. Wschr. 52, 9.

Aubertin \& Grellety-Bosvil. Cited by A. Clerc (1927).

Barrenscheen (1912). Zur Frage der akuten Leukämie. Wien. klin. Wschr. 25, 293.

BAUER, J. (1917). Die konstitutionelle Disposition zu inneren Krankheiten. Berlin.

Biermer (1861). Ein Fall von Leukämie. Virchows Arch. 20, 552.

BrandenberG, F. (1909). Über familiäres Auftreten der chronischen Leukämie. Fortschr. Med. No. 31. (1910). Arch. Rassen- u. Ges. Biol. 


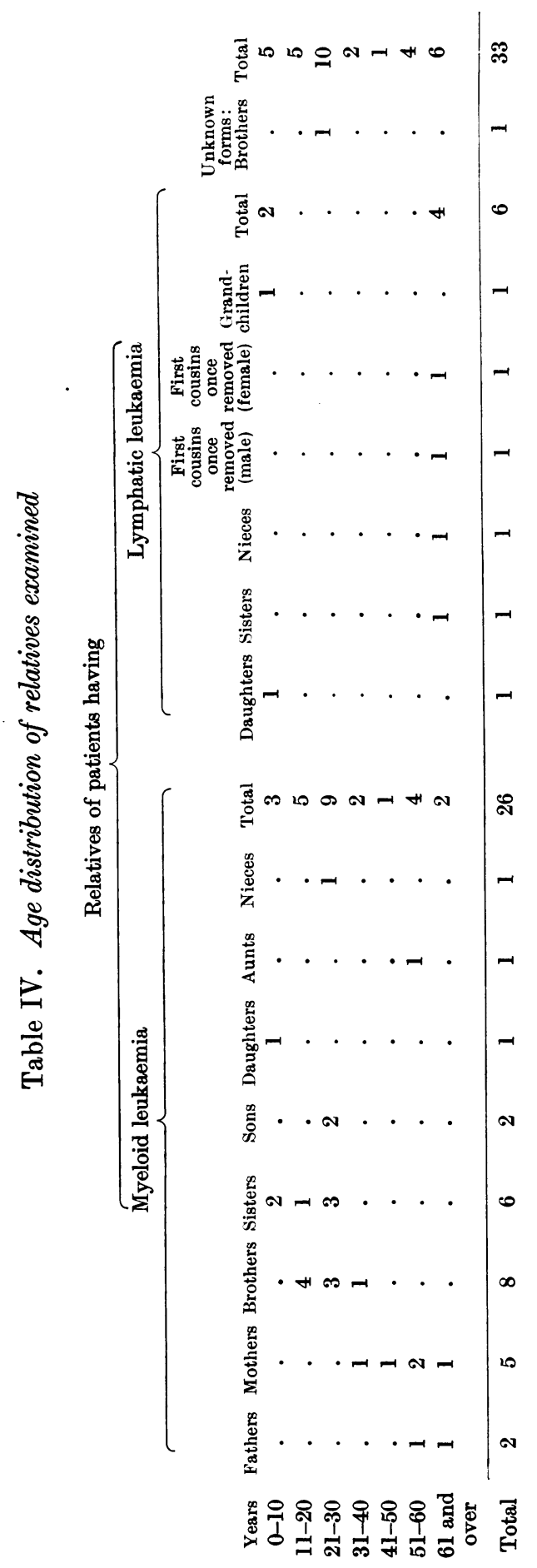


BRÜGGER (1927). Familiäres Vorkommen von Leukämie. Münch. med. Wschr. 74, 683.

Cameron. Cited by Petri (1933).

Campbell (1912). A discussion about myelogenous leukaemia. Lancet, i, 1473.

Casati. Cited by Senator (1882).

Clerc, A. (1927). Affections du sang et de Médecine, 9, 327. Paris.

Dameshek, W., Savitz, H. A. \& Arbor, B. (1929). Chronic lymphatic in twin brothers aged fifty-six. J. Amer. Med. Assoc. 92, 1348.

Decapite. Cited by Petri (1933).

Erchrorst, C. (1897). Handbuch der speciellen Pathologie und Therapie für praktische Arzte und Studierende (5 Aufl.), 4, 3.

Eppinger, B. (1911). Diskussion über den Vortrag Sternberg's. Wien. klin. Wschr. 24, 1655.

GrawtTz (1907). Clinical Pathology of the Blood. (Russian.) St Petersburg.

Greene, J. L. Cited by Grawitz (1904).

Hanszel, F. (1908). Zur Diagnose der akuten lymphoiden Leukämie im Rachen. Wien. klin. Wschr. 21, 594 .

Hirschfeld, H. Cited by Rosenow (1925) and Dameshek et al. (1929).

Holbøl, S. A. (1929). Untersuchungen über den Grundumsatz bei Patienten mit Leukämie und Lymphogranulomatose. Acta med. Scandinav. 72, 326.

JewetT. Cited by MacGavran (1922).

Levit, S. G. (1935). Sex-linked genes in man (their relation to the problem of dominance). C.R. Acad. Sci. U.R.S.S. 2, Nos. 5-6, 428-34.

- (1935). Dominance in man. Ibid. 2, No. 7, 499-504.

- The problem of dominance in man. Proc. Maxim Gorky Med. Genet. Res. Inst. 4. Moscow.

MacDowell, E. C., Potter, J. C. \& Victor, J. (1934-5). Leukemia studies. Ann. Rep. Dep. Genetics, Carnegie Inst. of Washington, Year Book, No. 34, p. 44.

MacDowell, E. C. \& Richter, M. N. (1930). Hereditary susceptibility to inoculated leukemia. J. Cancer Res. 14, 434.

(1931). Specificity of susceptibility to different lines of inoculated leukemia. Proc. Soc. Exp. Biol. Med. 28, 1012.

- (1932). Genetic analysis of susceptibility to inoculated leukemia of Line I. Biol. Zbl. 52, 266.

MacGavran (1922). Three cases of leukemia in one family. Amer. J. Med. Sci. 164, 545.

Mannaberg. Cited by Bauer (1917).

MoRawitz (1933). Erblichkeit und Konstitution bei Leukämien. Münch. med. Wschr. 80, No. 31 .

NAEGELI (1923, 1931). Blutkrankheiten und Blutdiagnostik.

Obrastzow, W. (1891). Zwei Fälle von akuter Leukämie. Dtsch. med. Wschr. 16, 1150.

Ortwer, N. Cited by Petri (1933).

Petri, Sevend (1933). Über familiäres Auftreten der Leukämie. Acta Path. Mikrobiol., Scandinavia, 10, F. 4.

Presnyakov, D. F. (1936). Clinico-genetical investigation of pernicious anaemia. Proc. Maxim Gorky Med. Genet. Res. Inst. 4.

Riccitteli \& Ragnotti. Cited by Morawitz (1933).

Richter, M. N. (1930). The experimental transmission of leukemia. J. Exp. Med. 51, No. 4.

Richter, M. N. \& MacDowell, E. C. (1929). The experimental transmission of leukemia in mice. Proc. Soc. Exp. Biol. Med. 26, 362.

(1930). A comparison of four lines of leukemia transmitted by inoculation. J. Exp. Med. 52, 823.

RosenHAUPT, HEINRICH (1915). Kasuistische Beiträge zur Vererbungsfrage bei der akuten Leukämie. Kinder Arzt, 26, No. 4. 
Rosenow (1925). Blutkrankheiten. Berlin.

SChEReschewsky, E. (1926). Über einen Fall von Geschwisterleukämie. Zbl. inn. Med. No. 26, p. 643.

Schmorl. Cited by Petri (1933).

Senator (1882). Zur Kenntniss der Leukämie und Pseudoleukämie im Kindesalter. Berlin klin. Wschr. 35, 533.

Steiner, V. (1933). Familiäre Leukämie. Münch. med. Wschr. No. 46, p. 1822.

Sternberg (1911). Über die echte myeloide Leukämie. Wien. klin. Wschr. 24, 1923.

Vercelotti. Cited by Petri (1933).

WeIsZ, J. (1911). Diskussion über den Vortrag Sternberg's, 17 Nov. 1911. Wien. klin. Wschr. $24,1656$.

(MS. received for publication 18. xI. 1936.-Ed.) 